DOI: https://doi.org/10.31933/dijdbm.v2i2

Received: 27 December 2020, Revised: 20 January 2021, Publish: 1 March 2021

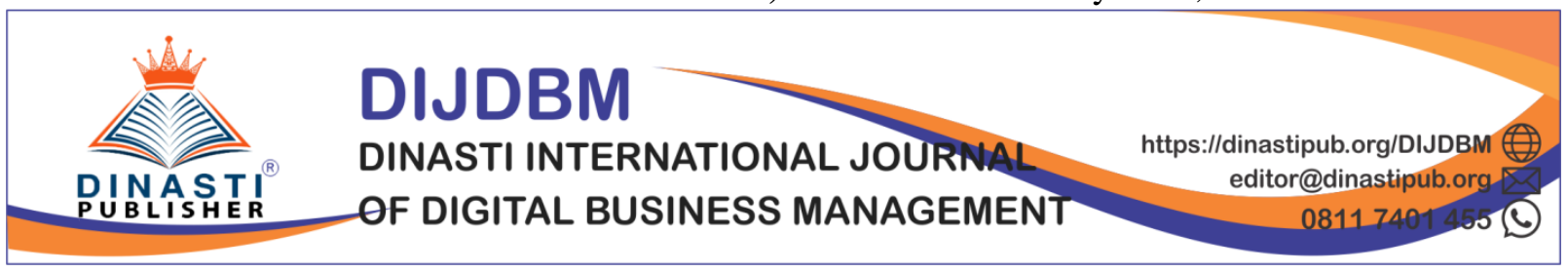

\title{
THE ROLE OF JOB SATISFACTION AS AN INTERVENING VARIABLES IN AFFECTING THE EMPLOYEE PERFORMANCE
}

\author{
Herawati Herawati ${ }^{1}$, Nia Kusuma Wardhani ${ }^{2}$ \\ ${ }^{1)}$ Universitas Mercu Buana, Jakarta, Indonesia, herawatihidayat.76@gmail.com \\ ${ }^{2)}$ Universitas Mercu Buana, Jakarta, Indonesia, nia.kusuma@mercubuana.ac.id
}

\section{Corresponding Author: Herawati}

\begin{abstract}
In a competitive environment, every organization certainly has the same goal, namely to have potential human resources. Therefore, every organization should be able to find the best solution to each problem to interrupt the expected performance growth. This research aims to analyze the importance of the role of job satisfaction in mediating the affect of Transformational Leadership Motivation on the operators production performance at PT. Alpen Food Industri Cikarang, West Java. This research population was 189 people, with a total sample of 133 employees. The sampling technique in this research used random sampling with a method of organizing data through questionnaires and interviews, quantitative research methods with analytical analysts that job motivation and transformational leadership affect job satisfaction and performance. Meanwhile, the mediating variable of job satisfaction is good for mediating work motivation and transformational leadership on performance. Path analysis earned the structural equation $Y=0.250 X 1+0.391 X 2+0.150 Y 1+0.525$, so the transformational leadership is the variable which has the strongest affect on performance.
\end{abstract}

Keywords: Job satisfaction, work motivation, transformational leadership, performance.

\section{INTRODUCTION}

Job satisfaction is an employees' emotional feeling towards their jobs, Kardam and Ranekar (Saeka \& Suana, 2016). The Incline in job satisfaction is the key to the advance of an organization. It becomes fundamental for companies to identify what employees want and their desired work environment and it could improve its service to employees. (Ni Kadek, at al 2015).

Various problems which arise in production operator employees at PT. AFI was cause by low work motivation, among others, a leadership style that did not provide a sense of comfort on workers and job satisfaction which is still lacked. The impact of those issues occured at PT. AFI has resulted in a turnover which has an affect on the performance of production operators employees at PT.AFI. 
According to one porter employee "Bima", the number of employees who resigned cause of many complaints from them such as the company did not upgrade their salaries though they already worked for about 2 to 3 years, besides there was no policy from their superiors to listen to their complaints. And the unavailability of health support facilities for the production operator employees at PT.AFI.

Based on the background of problems above, the researcher took the research title of "The role of Job Satisfaction as an Intervening Variables in Affecting the Employee Performance".

The aims of this analysis are: 1) To reveal and justify regarding the affect of motivation towards job satisfaction on employees at PT. Alpen Food Industri; 2) To reveal and justify regarding the affect of transformational leadership towards job satisfaction at PT. Alpen Food Industri; 3) To reveal and justify regarding the affect of motivation on employees performance at PT. Alpen Food Industri; 4) To reveal and justify regarding the affect of transformational leadership on employees performance at PT. Alpen Food Industri; 5) To reveal and justify regarding the affect of job satisfaction on employee performance at PT. Alpen Food Industri; 6) To reveal and justify regarding the indirect affect of motivation on performance through mediation of job satisfaction variable; and 7) To reveal and justify regarding the indirect affect of transformational leadership on performance through mediation of job satisfaction variable.

\section{LITERATURE REVIEW Motivation}

The root of the word motivation is motive, namely encouragement means a reason or excuses to do something, therefore the motivation refers to a situation which encourages or becomes the cause of an activity (Hidayat et al., 2017:92). According to Ardiaz, et al. (2017), the motivation is a very important role for a group of people who work together individually to achieve certain goals in each group work. There are two types of work motivation, such as positive motivation and negative motivation Hasibuan (Buila, at al. 2017).

1) Positive motivation (positive incentives) Positive motivation means the leader motivates (encourages) subordinates by giving rewards to those who excel above the standard. By positive motivation, the morale of subordinates would increase because people generally like to received the kindness.

2) Negative motivation (negative incentives) Negative motivation means the leader motivates their subordinates according to the standard of punishment. Through this negative motivation, the morale of subordinates in the short term would increase because they are afraid of being punished, but it could have a negative impact in the long run.

The indicators of motivation variables which include in the provision of job opportunities, guarantee of work environment safety, protection from work risks, distribution of skills and achievements, placement, appropriate job placement, good cooperation.

\section{Transformational Leadership}

According to Naem \& Khanzada (2017) transformational leadership inherently complements the fulfillment of job satisfaction into its ability to communicate a sense of mission and work motivation. Usually transformational leaders have a tendency to provide 
confidence and could inspire workers, the workers would be more independent and responsible. According to Robbins \& Judge (2015) transformational leadership is leadership which inspires their followers to put their personal interests aside for the good of the organization and where they could have a tremendous affect on their followers.

The indicators of transformational leadership including trust, emphasis on vision and mission, increased loyalty, problem solutions, optimism and enthusiasm, respect for individuals.

\section{Job Satisfaction}

According to Hidayat, at al. (2017), job satisfaction related to the feelings which occur in each employee. The Feelings are very dynamic, which is related to the accumulation of several feelings, in other words the feelings are complex and complicated activities.

According to Sutrisno (Lidia \& Hotland, 2017) the factors which affect the job satisfaction: 1) Psychological factors which related to employee psychology such as interest, peace of mind at work and attitudes towards work; 2) Social factors are factors related to social interactions between employees and superiors; 3) Physical factors are factors related to the physical condition of employees at work, including types of work, arrangements for working hours and rest periods, work equipment and physical conditions at work; and 4) Financial factors are factors related to the safety and welfare of employees, including the system and amount of salaries, social security and promotion opportunities. Job satisfaction variable indicators including job perfectly with skills, given responsibilities, learning opportunities, match of salaries of work, suitability of allowances, incentives, technical assistance, moral support, supervision provided, promotion and equal opportunities.

\section{Performance}

Performance is the result of the quality and quantity of work which an employee gets in carrying out their duties according to the responsibilities that they carry (Mangkunegara, 2015).

According to Kasmir (2016:65-71), the factors which affect performance are: 1) Talent and knowledge are the expertise or skills of a person to do a job. No matter how many skills or expertise you have, you can get the job done right; 2) Knowledge, someone with good business knowledge will give good business results; 3 Job design, that could make it easier to achieve your goals. So that if a job has a good design, it would be easier to do the job correctly and accurately; 4) Work motivation is a determined factor for someone to do business. Work motivation becomes a person's motivation to do business if the employees have a strong influence. If the employee has strong motivation, they will do a good job; 5) Leadership is the behavior of a leader to manage, direct and leads their subordinates to carry out certain tasks and responsibilities; and 6) Job satisfaction is a feeling of pleasure before and after doing a job. If employees are happy, the work that they do would be great. The Indicators of performance variables include sequences, the accuracy of business results, number of units produced, effectiveness, future plans, self-discipline, cooperation, and consistency.

The success of organization highly depends on humans as resources who carry out work, including reciprocal relations that would be received by workers such as job satisfaction, work 
motivation and transformational leadership styles, and many more which would drive the improvement of employee performance in the organization.

\section{Theoretical Framework}

As for theoretical framework that author could bedrawn as follows:

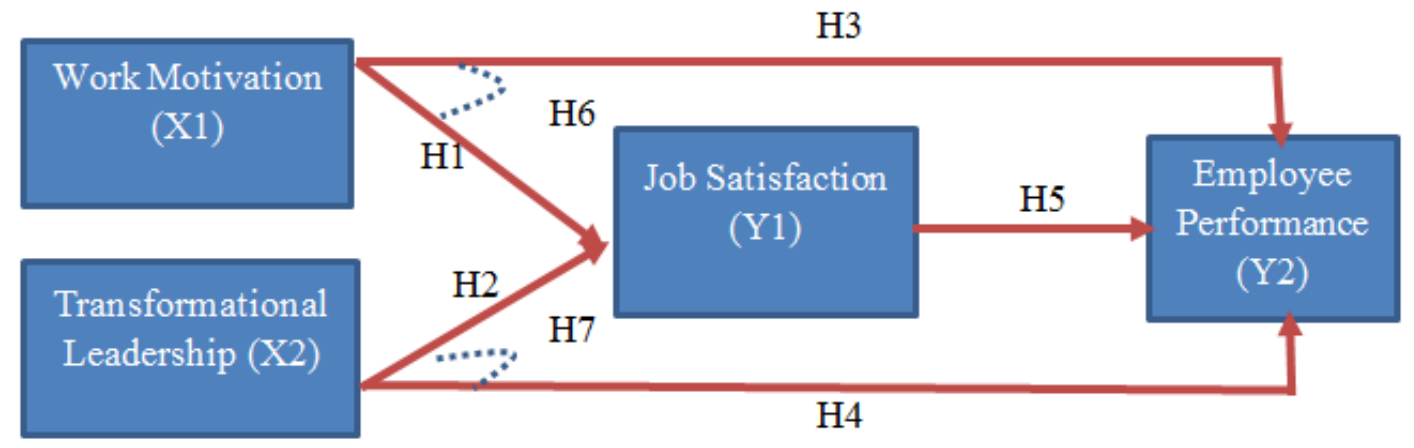

Figure 1. Theoretical Framework

\section{Hypothesis}

Based on these data gathered above, the researcher proposes several hypothesis such as:

H1: Work motivation has an influence on job satisfaction

$\mathrm{H} 2$ : Transformational leadership has an influence on job satisfaction

H3: Work motivation has an influence on performance

H4: Transformational leadership has an influence on performance

H5: Job satisfaction has an influence on performance

H6: Job motivation indirectly influence the employee performance through mediation variable of job satisfaction.

H7: Transformational leadership indirectly influence the employee performance through mediation variable of job satisfaction.

\section{RESEARCH METHODS}

The quantitative method used in this research with a total population of 189 people and a sample of 133 people with the data analysis technique used was descriptive statistics. The descriptive statistics used to answer the formula, which proves that the influence of work motivation and transformational leadership on performance through job satisfaction as a mediator variable. In this research all data analysis was carried out with the support of SPSS version 23 software. In this research, a path analysis mode used multiple linear regression model approaches.

\section{RESULT AND DISCUSSION Validity and Reliability Test}

Validity is a measure of the value of an instrument. Therefore, the validity test shows the extent to which a tool fulfills its function. To reveal the validity of an item, we connect the item score to the number of the item. If the $r$ - value was greater than r-table, then the item was declared valid. Thus, it could be said if all the indicators were valid. While the reliability test is 
useful for investigating whether the tool could be used more than once in these terms, at least the consistent data would be generated by the same respondents. In other words, the instrument reliability reflects the level of consistency. The reliability value was expressed by Cronbach's Alpha coefficient of 0.6 according to the criteria of the lowest reliability limit. If the standards are met, the survey was declared reliable.

Table 1. The Validity and Reliability Test Results

\begin{tabular}{|l|l|l|c|}
\hline \multirow{2}{*}{ Variable } & \multicolumn{1}{|c|}{ Validity } & \multicolumn{2}{c|}{ Reliability } \\
\cline { 2 - 4 } & \multicolumn{1}{c|}{$\begin{array}{c}\text { Valid } \\
\text { Question }\end{array}$} & $\begin{array}{c}\text { Cronbach' } \\
\text { Alpha Value }\end{array}$ & $\begin{array}{c}\text { Level of } \\
\text { Reliability }\end{array}$ \\
\hline Motivation & 14 & 0.981 & Perfect \\
\hline $\begin{array}{l}\text { Transformational } \\
\text { Leadership }\end{array}$ & 14 & 0.989 & Perfect \\
\hline Job Satisfaction & 16 & 0.981 & Perfect \\
\hline $\begin{array}{l}\text { Employee } \\
\text { Performance }\end{array}$ & 12 & 0.989 & Perfect \\
\hline
\end{tabular}

\section{Classic Assumption Test}

The normality test has a goals to discover if the dependent variable (limit) and the independent variable (free) has its contribute to the regression model. A good regression model is data which is normally distributed or nearly normal. "The decision making over the data normality which is if the data is scattered around the cross line and following the cross line, then the regression fills the normality and conversely.
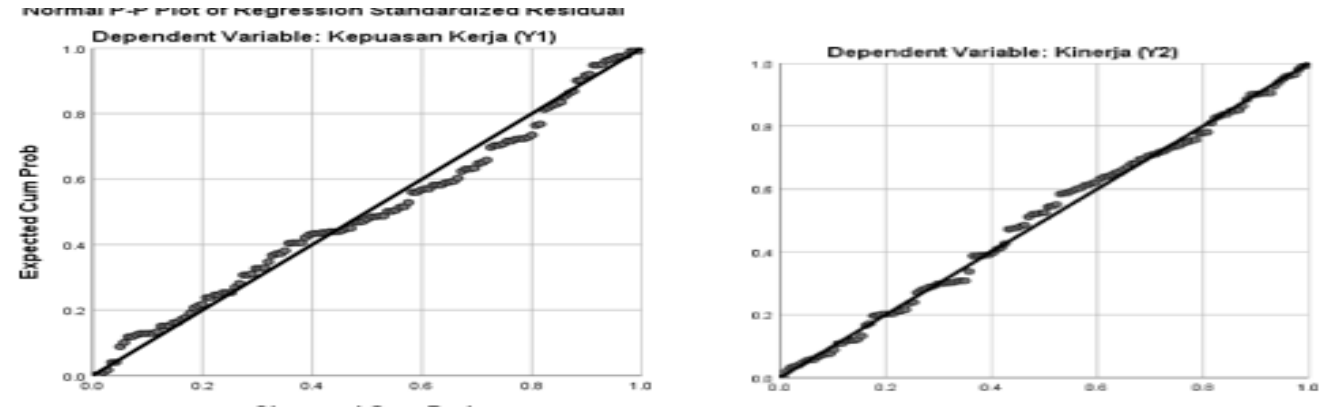

Figure 2. Normality Test Results

The multicollinearity test has purposes to examine whether the data in this regression model found a correlation between the independent variables and other independent variables. The multiple correlation test results in Tables 4.12 and 4.13 shows that the tolerance value was greater than 0.1 and the VIF value of the variable does not exceed 10 , so it could be concluded that there is no multiple correlation between variables. 
Table 2. Multicollinearity Test Results

\begin{tabular}{|l|c|c|c|c|}
\hline \multirow{2}{*}{ Variable } & \multicolumn{2}{|c|}{ Regression 1 } & \multicolumn{2}{c|}{ Regression 2 } \\
\cline { 2 - 5 } & Tolerance & VIF & Tolerance & VIF \\
\hline Work Motivation & .402 & 2.486 & .339 & 2.951 \\
\hline $\begin{array}{l}\text { Transformational } \\
\text { Leadership }\end{array}$ & .402 & 2.486 & .332 & 3.013 \\
\hline
\end{tabular}

Different variance test aims to examine whether there is an inequality of residual variance from one observation to another in this regression model. According to the test results in the image above, it could be said if there is no signs of heteroscedasticity in the regression model, because the points has a random distribution pattern above or below the number 0 which are visible to the $\mathrm{Y}$ axis.
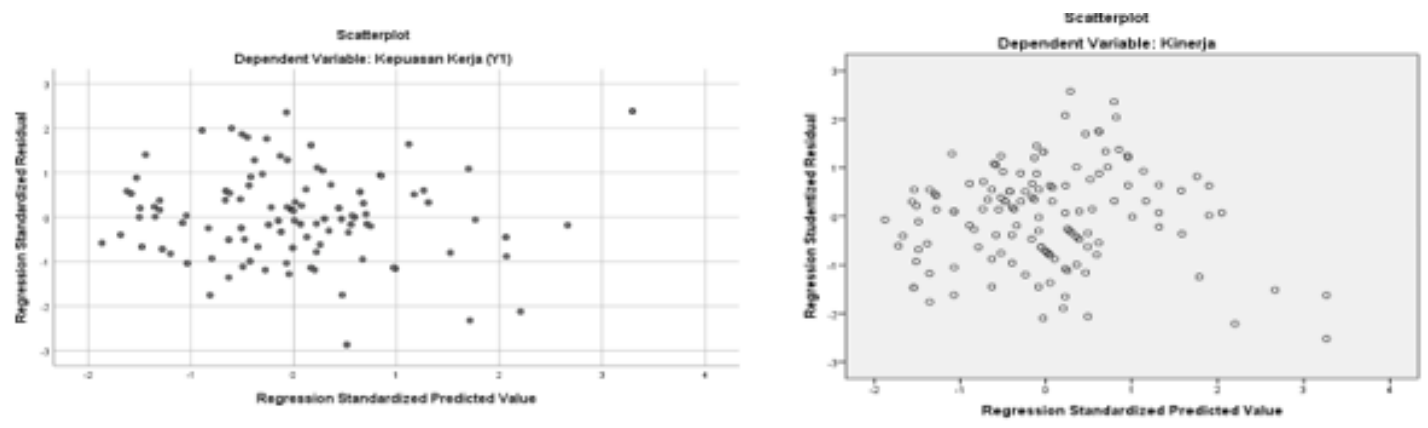

Figure 3. Heteroscedasticity Test Results

\section{Multiple Linear Regression Analysis}

From this page the variables of the regression test, work motivation (X1), transformational leadership (X2) and performance variables which is job satisfaction (Y1) and performance (Y2). The estimation of the rules in multiple regression analysis through the assist of Spss version 23.

Table 3. The Multiple Linear Regression Analysis Results on the First Regression Equation

\begin{tabular}{lccccc}
\hline & \multicolumn{2}{c}{$\begin{array}{c}\text { Unstandardized } \\
\text { Coefficients }\end{array}$} & $\begin{array}{c}\text { Standardized } \\
\text { Coefficients }\end{array}$ & & \\
\cline { 2 - 6 } Model & $\mathrm{B}$ & Std. Error & Beta & $\mathrm{t}$ & $\mathrm{Sig}$ \\
\hline Constant & .326 & .128 & & 2.542 & .012 \\
\hline Motivation (X1) & .407 & .083 & .411 & 4.933 & .000 \\
\hline Transformational & .463 & .088 & .437 & 5.248 & .000 \\
Leadership (X2) & & & & & \\
\hline
\end{tabular}

The estimation equation in regression model 1 is: $\mathrm{Y}=0.326+0.407 \mathrm{X} 1+0.463 \mathrm{X} 2+\mathrm{e}$. Based on the output of regression model lin the Coefficient table section, it can be described that the significance value of these two variables, which is $\mathrm{X} 1=0.000$ and $\mathrm{X} 2=0.000$, was smaller than 0.05. These results provided the conclusion that Regression Model 1 which variables are $\mathrm{X} 1$ and $\mathrm{X} 2$ have a significant influence on $\mathrm{Y} 1$ with the amount of the $\mathrm{R}$ Square value contained in the Model Summary table was 0.637, this shows that the contribution of the influence from X1 and X2 on Y1 was $63.7 \%$ with the remaining of $36.3 \%$ was determined by 
other variables outside the research. Meanwhile, the value of e1 could be found by the formula of $\mathrm{e} 1=\sqrt{(1-0,637)}=0.602$ thus the path diagram for model 1 was drawn as follows:

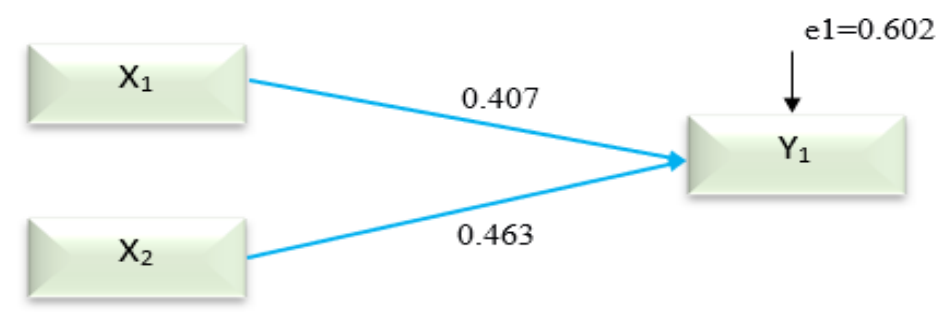

Figure 4. Path Analysis 1

Direct affect on the first regression model: 1) The influence of motivation (X1) towards job satisfaction (Y1): 0.407; and 2) The Influence of Transformational Leadership (X2) towards Job Satisfaction: 0.463.

Table 4. Multiple Linear Regression Analysis Results on Second Regression Equation

\begin{tabular}{llllll}
\hline & \multicolumn{2}{l}{$\begin{array}{l}\text { Unstandardized } \\
\text { Coefficients }\end{array}$} & $\begin{array}{l}\text { Standardized } \\
\text { Coefficients }\end{array}$ & \\
\cline { 2 - 6 } Model & $\mathrm{B}$ & Std. Error & Beta & $\mathrm{t}$ & Sig \\
\hline 1.Constant & 2.259 & .096 & & 23.461 & .000 \\
Motivation (X1) & .250 & .066 & .302 & 3.793 & .000 \\
Transformational & .391 & .071 & .441 & 5.496 & .000 \\
Leadership (X2) & & & & & \\
Job Satisfaction (Y1) & .150 & .064 & .179 & 2.330 & .021 \\
\hline
\end{tabular}

The estimation equation in this regression Model 2 is: $\mathrm{Y}=2.259+0.250 \mathrm{X} 1+0.391 \mathrm{X} 2$ $+0.150 \mathrm{Y} 1+\mathrm{e}$. In the regression output model II which included in this coefficient table, which could be seen that the significant value from these three variables, which is $\mathrm{X} 1=0,000, \mathrm{X} 2=$ 0,000 and $\mathrm{Y} 1=0.021$ has less than 0.05 and the variables of $\mathrm{X} 1, \mathrm{X} 2$ and $\mathrm{Y} 1$ have a significant impact on Y2.. While the value of R Square in the Model Summary was 0.724, this indicates if the contribution of $\mathrm{X} 1, \mathrm{X} 2$ and $\mathrm{Y} 1$ to $\mathrm{Y} 2$ was $72.4 \%$, while the remaining $27.6 \%$ was influenced by other variables which not examined in this research. As for the value of e2 $=$. Thus the path diagram for the regression model II was obtained as belows:

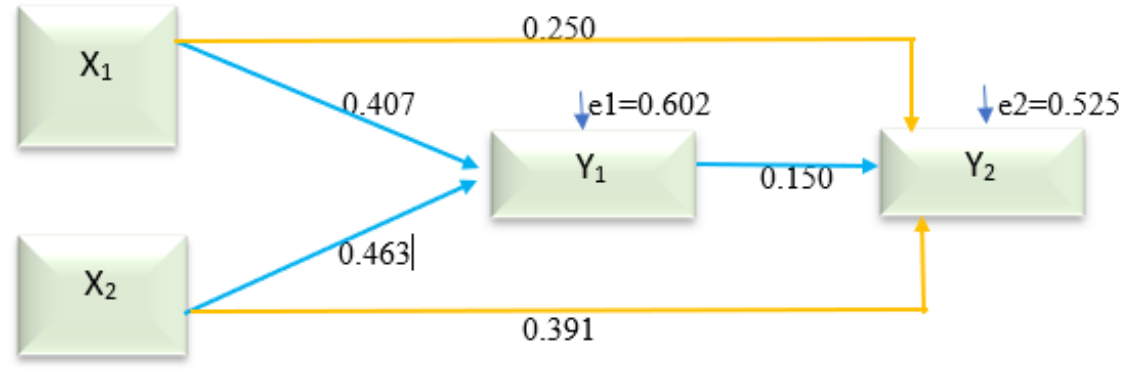

Figure 5. Path Analysis 2 
Direct influence on the second regression model was: 1) The Influence of Motivation (X1) on Performance (Y2) $=0.250 ; 2$ ) The Influence of Transformational Leadership (X2) on Performance $(\mathrm{Y} 2)=0.391$.

The Indirect effect: 1) The Influence of Motivation (X1), through Job Satisfaction (Y1) towards the Performance $(\mathrm{Y} 2)=0.407 \times 0.150=0.061$ with total influence of $0.250+0.061=$ 0.311 ; and 2) The Influence of Transformational Leadership (X2) through Job Satisfaction (Y1) on Performance (Y2) was $0.463 \times 0.150=0.069$ with total Influence of $0.391+0.069$

\section{ANOVA Test Results}

ANOVA test results on regression 1earned F-number was 114.234 which was greater than F-table 0.361 and P-value 0.000 smaller than the significant value level 5\% $(\alpha=0.05)$; This illustrates if the business motivation and transformational leadership have a significant affect. Job satisfaction is simultaneous at PT Alpen Food Industri. Meanwhile, as for the ANOVA test results in regression 2, F-value of 112,661 which is greater than the F-table of 0.361 , and $P$-value of 0,000 was smaller than $5 \%$ significant value $(\alpha=0.05)$. This shows that the work motivation (X1) and Transformational Leadership (X2) simultaneously affect employee performance at PT Alpen Food Industri (Y2).

Table 5. The F-test Results (ANOVA)

\begin{tabular}{|c|c|c|}
\hline Model & F-count & Sig. \\
\hline Regression 1 & 114.234 & 0.000 \\
\hline Regression 2 & 112.661 & 0.000 \\
\hline
\end{tabular}

\section{GoF Model Test}

The p-value in the regression model 1 and regression model 2 was greater than 0.05 in the sobel test, then it could be concluded that the work motivation variable which mediated by job satisfaction is not significant in terms of performance. Likewise, the job satisfaction to transformational Leadership which not be a matter with the mediated performance.

Table 6. Sobel Test Results

\begin{tabular}{|l|l|l|l|}
\hline Model & Statistical Tests & Std. Error & P-Value \\
\hline Regression 1 & 0.55042766 & 0.12808223 & 0.58202608 \\
\hline Regression 2 & 0.51336034 & 0.13528509 & 0.60769928 \\
\hline
\end{tabular}

\section{Discussion}

\section{The Influence of Work Motivation on Job Satisfaction on the Performance of Production} Operators at PT. Alpen Food Industri

The results from the first hypothesis test which stated that work motivation at PT.AFI has a positive influence through job satisfaction on production operator employees. Meaning that 
the better the work motivation they have, the better the performance of production operator employees at PT.AFI.

Work motivation has a positive affect on job satisfaction in production operator employees, because if the work motivation received by employees such as job opportunities provided by the company and also those rewards given from their superiors consider as good, then the job satisfaction felt by employees would increase. This research results was indicated has a positive affect on motivation, for example through the job satisfaction.

From this correlation matrix results, the dimension of the motivation variable which has the strongest relations to the dimensions of the job satisfaction variable is the physiological need dimension (X1.1) to the promotion dimension (Y1.4). Physiological needs refers to the basic needs for employees at PT.AFI, namely the need to complement desired to develop their talents and achievements and to retain the increased in productivity.

\section{The Influence of Transformational Leadership through Job Satisfaction on Employees of Production Operators at PT. Alpen Food Industri}

The results from these second hypothesis test which stated if the transformational leadership has a positive affect through job satisfaction on production operator employees at PT.AFI.

Transformational leadership has a positive affect on job satisfaction at production operator employees, because the transformational leadership which consider good such as superiors always supports the company's vision and mission and if employees could sort of the problems, the employee satisfaction would increase. The results of this research are in line with Handoko, et al. (2015), and Dappa (2019), the results showed that there was a positive influence between transformational leadership and job satisfaction.

Based on this correlation matrix results, the dimension of the transformational leadership variable which has the strongest relations to the dimensions of job satisfaction variable is the inspirational motivation dimension (X2.4) to the supervision dimension (Y1.3). Inspirational motivation refers to the attention and enthusiasm of superiors in supporting employees to work, so they could provide the moral assistance needed by employees in various problems which often occured.

\section{The influence of motivation on the Production Operators performance at PT. Alpen Food Industri}

The test results from the third hypothesis which stated if the work motivation has a positive affect on the production operator at PT.AFI.

Work motivation has a positive affect on the performance of employees of production operator, because if the work motivation obtained by the employees is good, the employee performance will increase. The results of this research are in accordance with the research from Soelton (2016), Haruna (2019), Mira \& Natalia (2019). where th result shows that there is a positive impact between work motivation on performance. 
In the correlation matrix results, the dimension of the work motivation variable which has the strongest correlations to the dimensions of the performance variable is the physiological need dimension (X1.1) to the work quantity dimension (Y2.2). Physiological needs refer to the attention and enthusiasm of superiors in supporting employees to work, so that the employees would completed the work properly and in accordance with the targets given by the company.

\section{The Influence of Transformational Leadership on Employee Performance of Production Operators at PT. Alpen Food Industri}

The results from these fourth hypothesis test which stated that transformational leadership has a positive affect on the performance of production operator employees at PT. AFI.

Transformational leadership has a positive impact on employee performance of production operators because if the transformational leadership from good employees such as superiors always supports the company's vision and mission and would sort of employees problems, so the employee performance would increase. These results was in line with Herminingsih \& Supardi (2017), Purba \& Supangat (2016), and Dewi \& Amar (2019), the results shows a positive impact between the transformational leadership and performance.

The dimension of the transformational leadership variable which has the strongest correlation with the performance dimensions in the correlation matrix results is the motivation dimension (X2.4) which inspires the responsibility dimension (Y2.3). Inspirational motivation expresses the supervisor's concern and enthusiasm in encouraging employees to work so the employees could be careful in doing their work then they would provide satisfied results on their performance.

\section{The Influence of Work Motivation on Performance through mediation of Job Satisfaction on Employees of the Production Operators at PT. Alpen Food Industri}

In the Sobel test, the p-value of the regression model 1 and the regression model 2 was greater than 0.05 and according to the hypothesis test results, it could be illustrated that the indirect effect of work motivation on employee performance, the coefficient value of the direct effect of work motivation is lower than the coefficient value indirect one. Therefore, the priority on achieving the better employee performance is to improve work motivation without mediating job satisfaction. This research was in line with I Dewa Gede Yoga Sugama's research in 2017 and based on that it was found that job satisfaction cannot mediate work motivation on performance.

The Influence of Transformational Leadership towards the Performance through mediation of job satisfaction on Production Operators Employees at PT.Alpen Food Industri

Based on Sobel test, the p-value was greater than 0.05 in the regression models 1 and 2, and according to the hypothesis test results, it can be seen that the indirect effect of transformational leadership on employee performance is lower than its direct effect. Thus , in achieving better employee performance, the priority is given to improving the factors of better transformational leadership without mediating of job satisfaction. This research was in line with the findings of Siagian \& Khair (2018) and Pawirosumarto, et al. (2017), the results of 
their research has revealed if the job satisfaction cannot mediate transformational leadership in performance.

\section{CONCLUSION AND SUGGESTION Conclusion}

Based on the research results and discussion which mentioned previously, the researchers could draw several conclusions for PT Alpen Food Industry in maintenance the progress of its company which needs to be able to prioritize the needs of its employees, including motivation given, transformational leadership owned by superiors and job satisfaction which felt by employees, in the end all of that factors would have an impact on employee performance in the company. Those several conclusions could be written such as: 1) Work motivation, transformational leadership have a simultaneously positive impact on job satisfaction on the employees of the production operator at PT Alpen Food Industri; 2) Motivation had an impact towards job satisfaction on employees of the production operator at PT Alpen Food Industri; 3) Transformational leadership has an impact towards job satisfaction on employees of the production operator at PT. Alpen Food Industri; 4) Motivation has an influence on performance of employees of the production operator at PT Alpen Food Industri; 5) Transformational leadership has a positive impact on the performance of employees in the production operator division at PT. Alpen Food Industri; 6) Job Satisfaction has a positive affect on the performance of employees of the production operator at PT Alpen Food Industri; 7) Job satisfaction cannot mediate the work motivation indirectly on the performance of the production operators employees at PT Alpen Food Industri; and 8) Job satisfaction cannot mediate the transformational leadership indirectly on the performance of employees at PT Alpen Food Industri.

\section{Suggestion}

1) To increase the job satisfaction for employees of the production operator at PT Alpen Food Industri, the issue which needs to be the main attention is work motivation. This dimension that strongly influences job satisfaction is the physiological need for promotion, which includes the means by the company to facilitate opportunities for employees to get a higher position than before. Besides, PT Alpen Food Industri should prioritize the transformational leadership to establish employee morale through the training programs which provided and always support employees in providing technical assistance in various problems faced.

2) To enhance the performance of employees of the production operator at PT Alpen Food Industri, the dispute that should be the main attention is work motivation in the dimensions of physiological needs on the quantity of work on performance, namely in the availability of work support infrastructure, as a vessel for the work timeline to match determined targets and to ease the workload faced by employees. Besides, there is a strong influence between inspirational motivation on the dimensions of responsibility on performance, superiors should have transformational leadership towards employees, which aims to increase the employee responsibility for work in order to achieve maximum goals.

3) It is recommended for further researchers to look at the limitations of this research, thus it could be used as material for the development of further research in the future, by adding variables which have not been considered in this research which aimed at accelerating job satisfaction and performance. 


\section{REFERENCES}

Ardiaz, F., et al. (2017). Pengaruh Motivasi kerja dan Gaya Kepemimpinan Transformasional terhadap Kinerja dimediasi oleh Kepuasan kerja. Jurnal Bisnis dan Manajemen, 4(1).

Buila, I., et al. (2017). Transformational leadership and employee performance: The role of identification, engagement and proactive personality. International Journal of Hospitality Management.

Dappa, K., et al. (2019). A study on the effect of transformational leadership on job satisfaction: The role of gender, perceived organizational politics and perceived organizational commitment. Management Science Letters 9, 823-834.

Dewi, K., \& Amar, S. (2019). The Effect of Transformational Leadership, Interactional Justice, and Job Satisfaction on Performance. Third International Conference on Economics Education, Economics, Business and Management, Accounting and Entrepreneurship.

Handoko, A. \& Djastuti, I. (2015). Pengaruh Kepemimpinan Transformasional dan Motivasi kerja terhadap Kinerja Karyawan Dengan Kepuasan Kerja sebagai Variabel Intervening (Studi pada PT.Kereta api Indonesia (persero) Daop 4, Semarang). Diponegoro Journal of Management, 4(4).

Hasanuddin, H. (2019). Pengaruh Motifasi dan disiplin kerja terhadap kinerja pegawai pada secretariat DPRD profinsi Sulawesi Barat. Jurnal Ilmiah Ilmu Manajemen, 1(1).

Herminingsih, A., \& Supardi, W. (2017). The Effects of Work Ethics, Transformational and Transactional Leadership on Work Performance of Teachers. Management Studies, 5(3), 250-261. doi: 10.17265/2328-2185/2017.03.009

Hidayat, K., \& Hasbullah. (2017). Manajemen Sumber Daya Manusia. Jakarta: Wahana Resolusi.

Kasmir. (2016). Analisis Laporan Keuangan. Jakarta: Raja Grafindo Persada.

Lidia, L., \& Hotlan, S. (2017). Pengaruh Motivasi Kerja terhadap Kinerja Karawan melalui kepuasan kerja sebagai variable mediasi pada karyawan PT. Borwita Citra Prima Surabaya. Jurnal AGORA, 5(1).

Mangkunegara, A.P. (2015). Sumber Daya Manusia Perusahaan. Cetakan kedua belas. Remaja Rosdakarya. Bandung.

Mira, L., \& Paranoan. (2019). Pengaruh kepuasan kerja dan motivasi kerja terhadap kinerja dosen Fakultas ekonomi perguruan tinggi swasta di Makassar. Jurnal Akuntansi Netral, Akuntabel, Objektif, 1(2).

Naeem, S., \& Khanzada, B. (2017). Impact of Transformational Leadership in Attainment of Project Success: The Mediating Role of Job Satisfaction. International Journal of Business and Social Science, 8(9).

Pawirosumarto, S., et al. (2017). The effect of work environment, leadership style, and organizational culture towards job satisfaction and its implication towards employee performance in Parador Hotels and Resorts, Indonesia. International Journal of Law and Management, 59(6), 1337-1358.

Purba, C.B., \& Supangat. (2016). The Correlation Between Transformational Leadership Style and Organizational Culture with Performance of Sespimma Polri's Personnel in Jakarta. Jurnal Ekonomi, XXI(03), 436-443.

Purba, M. Y., \& Ruslan, S. (2020). INFLUENCE COMPENSATION, CAREER DEVELOPMENT AND JOB SATISFACTION TO TURNOVER INTENTION. Dinasti International Journal of Economics, Finance \& Accounting, 1(4), 642-658. 
Robbins, S.P., \& Judge, T. (2015). Prilaku Organisasi. Jakarta: Salemba Empat.

Sarinah, S. (2020). THE EFFECT OF JOB EVALUATION ON JOB SATISFACTION IN THE MERANGIN TOURISM, YOUTH AND SPORTS DEPARTMENT. Dinasti International Journal of Digital Business Management, 1(6), 980-986.

Sutiyem, S., Trismiyanti, D., Linda, M. R., Yonita, R., \& Suheri, S. (2020). THE IMPACT OF JOB SATISFACTION AND EMPLOYEE ENGAGEMENT ON ORGANIZATIONAL COMMITMENT. Dinasti International Journal of Education Management And Social Science, 2(1), 55-66.

Siagian, T.S., \& Khair, H. (2018). Pengaruh gaya kepemimpinan dan lingkungan kerja terhadap kinerja karyawan dengan kepuasan kerja sebagai variabel Intervening. Jurnal Ilmiah Magister Manajemen, 1(1), 59-70.

Soelton, M., et al. (2016). Pengaruh Gaya Kepemimpinan, Motivasi dan Kepuasan kerja terhadap Kinerja Caddy PT Sentul Highland Golf, Tbk, Bogor. Jurnal Ilmiah Manajemen dan Bisnis, 2(2).

Winasis, S., Djumarno, S. R., \& Ariyanto, E. (2020). THE IMPACT OF THE TRANSFORMATIONAL LEADERSHIP CLIMATE ON EMPLOYEE JOB SATISFACTION DURING THE COVID-19 PANDEMIC IN THE INDONESIAN BANKING INDUSTRY. PalArch's Journal of Archaeology of Egypt/Egyptology, 17(6), 7732-7742. 